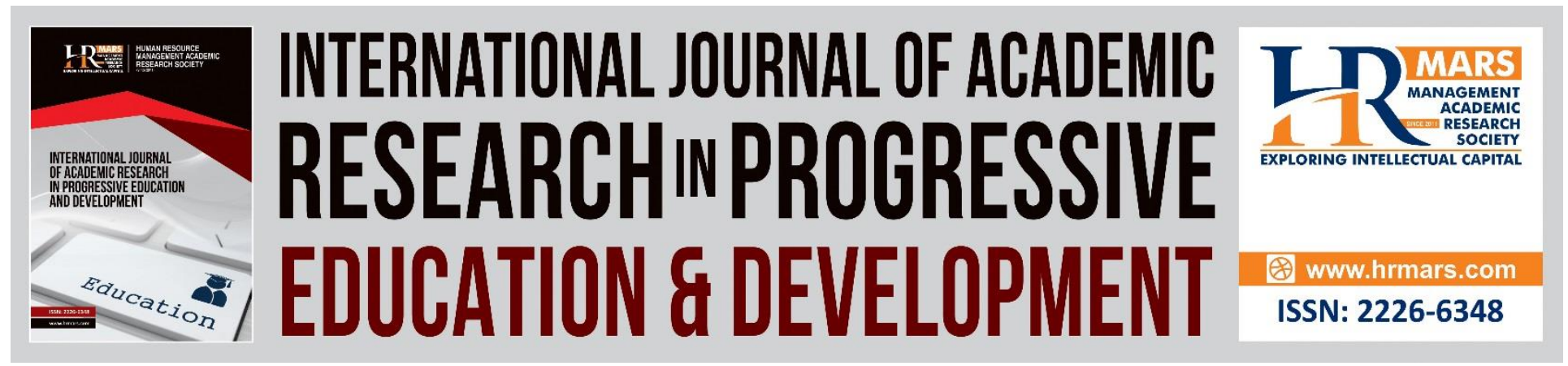

\title{
Gender and Labour Force Participation in Malaysia: Current Research and Future Direction on Gender Egalitarianism
}

Norhasni Zainal Abiddin, Affero Ismail

To Link this Article: http://dx.doi.org/10.6007/IJARPED/v10-i2/9791

DOI:10.6007/IJARPED/v10-i2/9791

Received: 01 March 2021, Revised: 27 March 2021, Accepted: 17 April 2021

Published Online: 20 May 2021

In-Text Citation: (Abiddin \& Ismail, 2021)

To Cite this Article: Abiddin, N. Z., \& Ismail, A. (2021). Gender and Labour Force Participation in Malaysia: Current Research and Future Direction on Gender Egalitarianism. International Journal of Academic Research in Progressive Education and Development, 10(2), 348-360.

Copyright: (C) 2021 The Author(s)

Published by Human Resource Management Academic Research Society (www.hrmars.com)

This article is published under the Creative Commons Attribution (CC BY 4.0) license. Anyone may reproduce, distribute, translate and create derivative works of this article (for both commercial and non-commercial purposes), subject to full attribution to the original publication and authors. The full terms of this license may be seen

at: http://creativecommons.org/licences/by/4.0/legalcode

Vol. 10 (2) 2021, Pg. 348 - 360

http://hrmars.com/index.php/pages/detail/IJARPED

JOURNAL HOMEPAGE

Full Terms \& Conditions of access and use can be found at http://hrmars.com/index.php/pages/detail/publication-ethics 


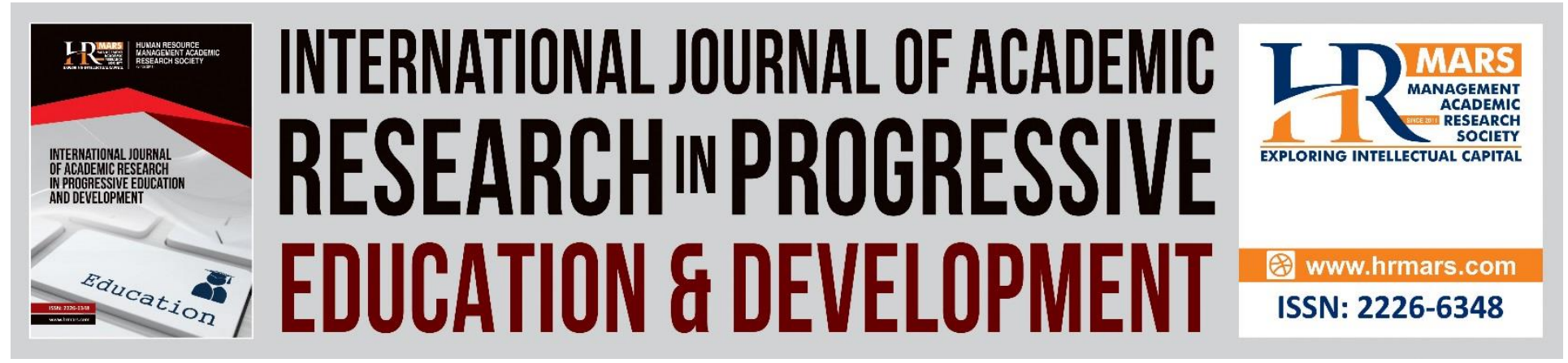

\title{
Gender and Labour Force Participation in Malaysia: Current Research and Future Direction on Gender Egalitarianism
}

\author{
Norhasni Zainal Abiddin \\ Universiti Pertahanan Nasional Malaysia \\ Affero Ismail \\ Universiti Tun Hussein Onn Malaysia
}

\begin{abstract}
Although, income inequality and poverty are being subtly addressed; the often-neglected link is that poor labour force participation among women has serious implications on endemic income inequality and poverty. Even though, women are acquiring knowledge, skills, abilities and other labour related characteristics like their men counterparts, they face considerable discriminations in the employment market. The continued labour participation imbalances against women are suggestive that, the current employment landscape is not yet inclusive and robust. In the current employment terrain, women are disproportionately disposed to making a compromise between paid job and home caring responsibilities. Although, the current review is not an exhaustive designed to cover every issue connected with gender labour participation disparity, the study will achieve the following key objectives. First, to bring into perspective the, underlying structural imbalance in female labour force participation. Second, to provide policy intervention which are necessary to improve female labour force participation. The review found that, while significant improvements have been made in terms of educational opportunities and economic liberalization which improved women participation, there are substantial structural, cultural and institutional impediments that are still holding women back. These obstacles require robust public policy advocacy, committed leadership in implementing relevant gender supportive behaviours.

Keywords: Gender, Labour Force Participation, Income Inequality, Egalitarianism, Workplace Discrimination

\section{Introduction}

Economic growth and development have taking a new turn, occasioned by rising technological innovations. While huge opportunities have been created in the midst of profound tech-
\end{abstract}


innovation, revolution and advancements; enormous challenges have emerged, especially in the context of rising income inequality, huge poverty, poor labour force participation for women and erosion of social fabrics. Although, income inequality and poverty are being subtly addressed; the often-neglected link is that poor labour force participation among women has serious implications on endemic income inequality and poverty (Djankov, Trumbic \& Zhang, 2020; Kelly, Watt, Hardie \& Lawson, 2021). The aging populations and dwindling labour productivity make an inclusive labour participation, a compelling economic and social issue to address (Kelly et al, 2021).

Even though, women are acquiring knowledge, skills, abilities and other labour related characteristics like their men counterparts, they face considerable discriminations in the employment market. The continued labour participation imbalances against women are suggestive that, the current employment landscape is not yet inclusive and robust (Djankov et al, 2020). In the current employment terrain, women are disproportionately disposed to making a compromise between paid jobs and home caring responsibilities. Also, in few of the available employment opportunities, women are compelled to accept lower pay compared to their men colleagues (Lagarde \& Ostrov, 2018).

The Covid-19 pandemic has worsened the gender pay disparity (Alon et al., 2020). This ugly development is credited to two factors which are linked together. The first is that, most of the sectors which were affected were those sectors that employ more women. The second is the sudden increase in home/family and care giving duties based on school shut down (Landivar et al., 2020). While these challenges may be easily visible in developed countries such as US, Canada, Japan, South Korea, UK and Australia due to available employment data; many developing countries with huge underlying economic, social and cultural problems are equally feeling the blunt of gender induced structural inequalities.

Although, the current paper is not an exhaustive review designed to cover every issue connected with gender labour participation disparity in Malaysia, the study will achieve the following key objectives.

1. To bring into perspective the, underlying structural imbalance in female labour force participation.

2. To provide policy intervention which are necessary to improve female labour force participation.

\section{Theoretical Foundation and Literature Review}

\section{Structural Imbalance in Labour Force Participation}

Although, women have increased their educational status and relevant skills in other to attain higher employment standing like their men counterparts, the supposedly skill improvement has not translated to job improvement and career prospects for women. Despite significant improvement in cultural, attitudinal and childcare policies in relation to gender gaps from the beginning of the century, female labour participation has been low even in developed countries (Lagarde \& Ostry, 2018). From the perspective of gender differences, female and male employees bring different skills into the workplace (Greenhaus, Peng \& Allen, 2012; Jolly et al., 2014; Lagarde, 2014). If the perspective of gender differences hold, female employees are more likely 
to be satisfied from their work and peers while male employees drive much satisfaction from supervisors and pay (Okpala, Squillace \& Erondu, 2005).

Also, from the viewpoint of work identity studies, female employees spend more time on family related responsibilities (Greenhaus et al, 2012). However, other scholars hold the views that male and female employees have similar characteristics (satisfaction and behavioural) on work related issues and where possible, the differences are negligible (Hyde, 2014; Powell \& Butterfield, 2013). The structural inequities in the employment landscape, even in developed economies negate the concept of egalitarianism, which is designed to promote fairness and justice in the workplace (Thijs et al., 2019).

While considerable gender improvements have been achieved, substantial discrimination and exclusion still exist (World Economic Forum, 2015).

\section{Theoretical Background}

Gender egalitarianism supports the notion of equality in terms of roles, rights and responsibilities. Essentially, gender egalitarianism is a belief system that hold the view that male and female should be treated equally in all economic, social and political landscape (Thijs et al, 2019). The perception that female is suited for homemaking and homecare while the male counterpart as the breadwinner falls short of the belief of gender egalitarianism (Davis \& Greenstein, 2009). Even though, gender disparity has reduced in developed countries, existing studies have not fully captured the within-differences among countries (OECD, 2017). While, macro-level economic policy and social contexts have been credited with little improvements in many advanced countries in terms of gender gaps (Kesler, 2018; OECD; World Economic Forum, 2015), substantial discriminations still exist in terms of social class, cultural disposition, education attainment and religious practices (Olivetti \& Petrongolo, 2017; Röder \& Mühlau 2014).

Educational attainment has reduced the gender gaps and, in many countries, girls have enrolled more than boys in primary and secondary schools. In countries, such as Morocco, India, Turkey and Indonesia, females are currently attending tertiary education more than males (OECD, 2016). Two major theoretical perspectives are principally adopted to explaining individual position on gender egalitarianism: (1) interest-based perspective and (2) socialization or exposure perspective (Thijs et al, 2019). While, interest-based theoretical perspective posits that individuals accept and preserve attitudes and behaviours which are consistent with their individual goals and interests (Bolzendahl \& Myers, 2004), socialization or exposure perspective argues that individuals adopt and preserve attitudes and behaviours when they are exposed to liberal or gender supportive beliefs (Davis \& Greenstein, 2009). Socialization or exposure, perspective is credited with increased in female egalitarian views because females are essentially in disadvantageous position unlike their male counterparts (World Economic Forum, 2015), thus supporting gender equality is benefial for them.

Men, in many conversative dominated societies like Malaysia are essentially driven by interestbased viewpoints (Bolzendahl \& Myers, 2004). In most of these societies, gender supportive beliefs would undermine their privileged positions (Davis \& Greenstein, 2009). Although, the two individual levels theoretical perspectives (interest and exposure) are necessary to understand the existing gender disparity (Thijs et al, 2019), they may not be sufficient to explain the continued changes in social- cultural development in the context gender egalitarianism. The pace of 
development has brought tremendous transformation, even in some conservative societies. The power of internet, social media and increasing gender supportive views are changing the perception on gender egalitarianism especially among the young, trendy and emerging adults. Social environment influences individual behaviours. People, generally adapt their lives in response to prevailing life circumstances (Alwin \& McCammon, 2003). Current social and environment events, commonly known as periodic effect may also influence behavioural disposition of a large population which would literacy affect individual attitudes within the particular period (Alwin \& McCammon, 2003). In view of the significant interest of women towards gender egalitarianism due to default disadvantageous position which women are consigned to (Bolzendahl \& Myers, 2004), it is expected that contemporary societal changes and concomitant gender egalitarianism, would be stronger among women compared to men (Doti Sani \& Quaranta, 2017).

Thijs et al (2019) examined the rising support for gender egalitarianism in Netherlands between 1979-2006. The study was primarily designed to examine the influence of education, labour force participation and secularization on gender egalitarianism. The study analysed cross sectional data involving 12,146 males and 13,858 females in other to examine the cohorts and petrolic effect. It was found that, out of the three indicators, only educational expansion influenced stronger gender egalitarianism among men and women respondents, which is suggestive that educational expansion has the strongest effect in prompting gender supportive behaviours among men and women.

\section{Gender Disparity in the Workplace}

While, educational opportunities are important determinant for stronger gender supportive behaviours (Dotti Sani \& Quaranta, 2017; Thijs et al, 2019), over reliance on educational attainment may not be effective in championing gender egalitarianism in every country or region. Banerjee (2019) examined female labour force participation in India based on educational attainment. The study found that social and cultural norms which tend to consign women as homemakers are the greatest impediments to improved female labour force participation. The finding is suggestive that educational expansion is an important determinant of gender egalitarianism may be context dependent. It is may be inferred that public advocacy would be vital in promoting the necessary social-cultural changes, which would sustain gender supportive behaviours.

Moodley (2018) examined the persistent gender inequality in South Africa despite local and international laws that are designed to promote gender equality. Specifically, the study explored relevant international and regional instruments which are critical in preserving women rights in the workplace. It was discovered that, lack of enforcement and compliance with existing laws and regulations were due to institutional failures. Also, gender supportive behaviours require improved public advocacy, engagement and proactive measures.

Organisations invest huge amount of money in other to be competitive and profitable. These resources are primarily targeted to improve employee productivity and organisational performance. However, organisational processes, systems, cultures and structures have remained stagnant in promoting gender egalitarianism. Stamarski and Son Hing (2015) found that persistent gender inequality in the workplace is largely due to HR induced practices driven by 
Vol. 10, No. 2, 2021, E-ISSN: 2226-6348 @ 2021 HRMARS

structural and systematic gender discriminations in work processes, systems, cultures and structures. Consistent with theoretical perspective of socialisation or exposure in the context of gender supportive behaviours, the current HR practices make it difficult to have balanced voices on matters relating to women rights and gender supportive behaviours.

\section{Figure 1}

\section{Reasons for gender disparity in the workplace}

\section{Why Are Women Restricted From Working?}

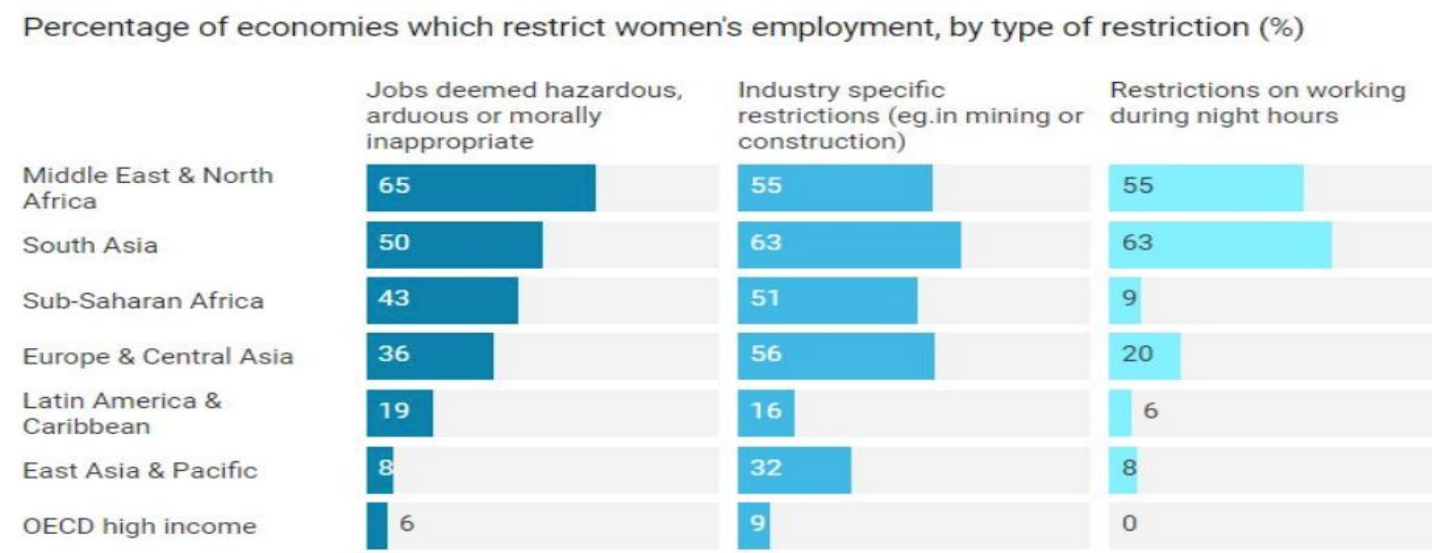

Source: (L. Mottaghi, 2019 as cited in Women, Business and the Law, 2018). The image was taken from WorlBank blog on $6^{\text {th }}$ March, 2019. Invest in women to boast growth in MENA.

Although, gender equity is improving in some regions and countries due to increasing advocacy for equality in many countries such as OECDs, little is achieved in many other countries or regions. As indicated in Figure 1, about 65\% of women from Middle East and North Africa were prevented from engaging in jobs deemed morally inappropriate or hazardous. Also, $50 \%$ of women in South Asia were equally discriminated, followed by $43 \%$ in Sub Sahara Africa, 36\% in Europe and centra Asia, 19\% in Latin American and Caribbean, $8 \%$ in East Asia and Pacific while OECDs and highincome nations accounted for $6 \%$. For industry specific restrictions such as mining and construction, South Asia top the list with $63 \%$ followed by Europe and centra Asia on 56\%. MENA (Middle East and North Africa) recorded 55\% while Sub Sahara Africa completed the top ranking with $51 \%$. Finally, restrictions due to time of work (nigh hours) showed that South Asia top the list with $63 \%$ followed by MENA with $55 \%$ and Europe and centra Asia with $20 \%$. From the information in Figure 1, it may be inferred that social-cultural factors are still the greatest impediments towards improved gender egalitarianism.

\section{Malaysian Women in the Workplace}

Employment opportunity is one of the most cited economic indicators in any economy. Particularly for individual and family members, employment opportunity represents the viable means to patriciate in the productive sector of the economy. Creating equal and inclusive employment opportunities in a developing economy such as Malaysia has been a cardinal economic, social and even national security issue. Although, 50\% of Malaysian working 
population are women, they repent $40 \%$ of the labour force. While series of intentions have been introduced to increase women labour force participation globally, many challenges continue to confront women, especially in a religious conservative country such as Malaysia.

Within the last decades, the favourable demographic factors which propelled Malaysia to the pinnacle of economic progress among the emerging the economies have started to change. World Bank (2019) report on Malaysia Women labour force participation, found that, increasing life expectancy and decreasing birth rate would require a new economic growth model that is based on efficient utilization of resources. Bridging the gaps between male and female labour force participation would, in the long run achieve a $26.2 \%$ increase in per capital income, which would translate to about RM 9,400 or \$2,300 (World Bank, 2019; p.11). However, achieving the above economic objective would require a reduction on three key barriers: labour force participation barrier, self-employment barrier and barrier that prevent women from becoming employers (World Bank, 2019; p.11).

Even though, women in Malaysia have shown significant educational attainment, they are still disproportionally represented in the workplace, compared to Malaysia neighbours such as Philippines, Indonesia and Myanmar. While educational attainment is important for economic and social mobility as evidenced by high proportion of women with formal education, it has not been effectively translated into strong women participation in the productive aspect of the economy. Unless, comprehensive and ingenious economic interventions is implemented, it may be difficult to achieve shared prosperity that is required to drive and sustain the emerging economic and social engineering in Malaysia. 


\section{Figure 2}

\section{Proportion of labour force participation by gender in Malaysia (1995-2017)}

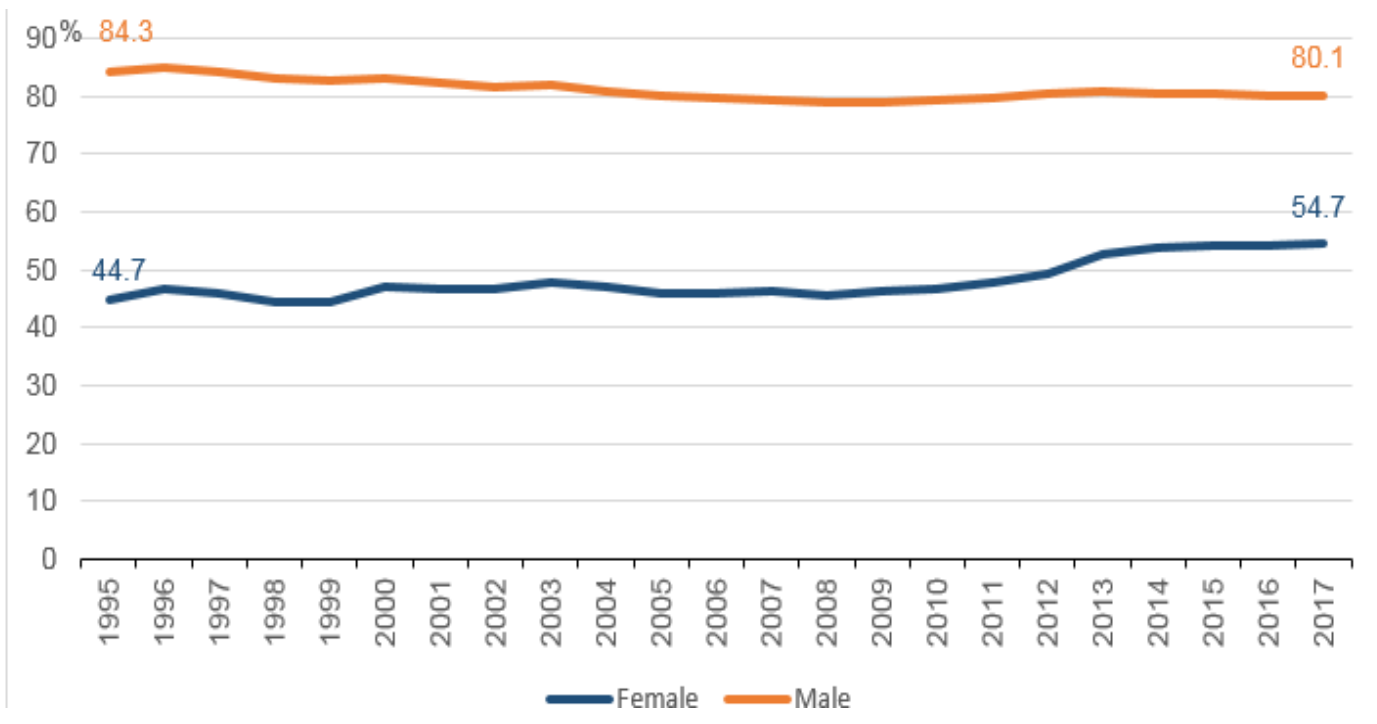

Source: (Chee and Gong, 2019 as cited in Department of Statistics Malaysia, 2018). The Figure was taken from Khazanah Research Institute website, 14 ${ }^{\text {th }}$ March, 2019. Khazanah Research Institute. 2019. Gender Role Values: What Do Women Want? Kuala Lumpur: Khazanah Research Institute. License: Creative Commons Attribution CC BY 3.0.

Labour force participation ratio has been a serious concern for policy makers both developed and developing countries. Figure 2 showed the labour force participation by gender in Malaysia between 1995 and 2017. Participation rate for male reduced marginally from $84.3 \%$ in 1995 to $80.1 \%$ in 2017 while participation rate for female increased from $44.7 \%$ in 1995 to $54.7 \%$ in 2017. While the information may seem encouraging for female due to $10 \%$ increase within the period, further probing of the result indicated a huge gap between male and female ( $80.1 \%$ vs. $54.7 \%)$, which gives a gender participation gap of $25.4 \%$. Although, the information didn't give the reasons for the huge gender participation gap, it painted a gory picture of widening female labour participation gap in relation to male in Malaysia. 


\section{Figure 3}

\section{Proportion of Malaysia working adults who are not working due to housework responsibilities (2005-2017).}

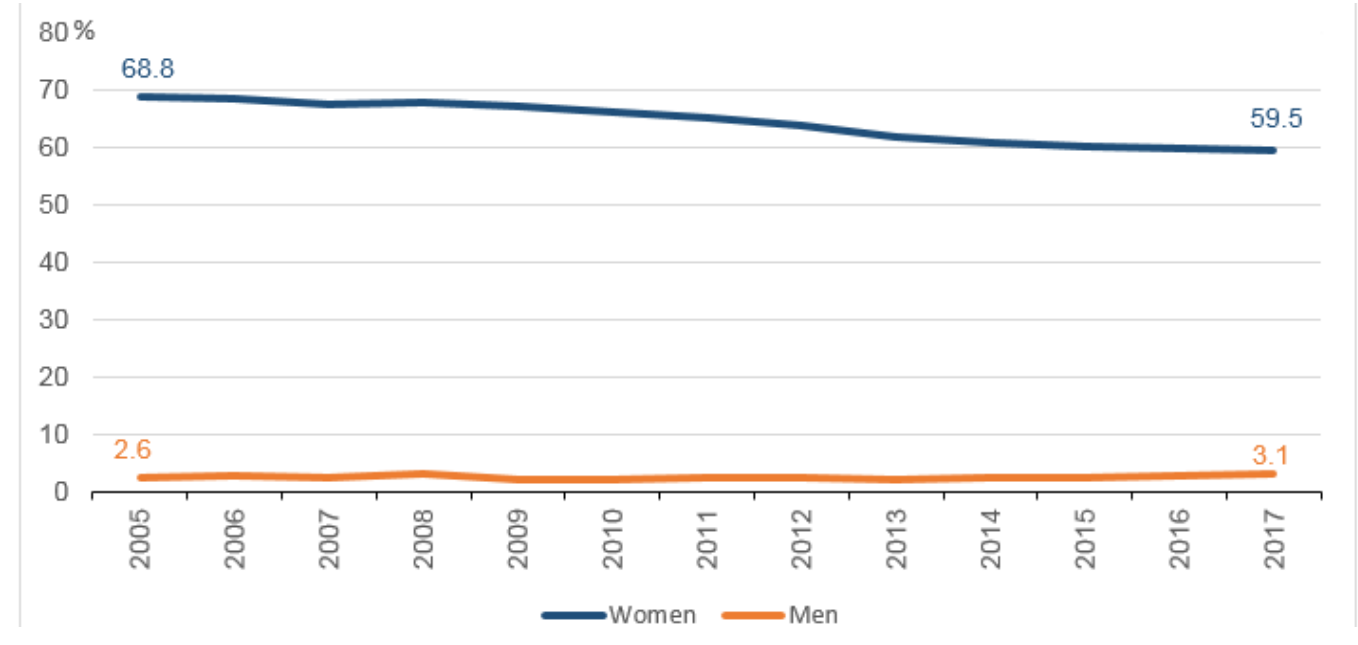

Source: (Chee and Gong, 2019 as cited in Department of Statistics Malaysia, 2018). The Figure was taken from Khazanah Research Institute website, 14 ${ }^{\text {th }}$ March, 2019. Khazanah Research Institute. 2019. Gender Role Values: What Do Women Want? Kuala Lumpur: Khazanah Research Institute. License: Creative Commons Attribution CC BY 3.0

Figure 3 indicated the proportion of Malaysia working adults who cited home work responsibilities as the reason for not working between 2005-2017. From the information, it was discovered the information for male was relatively flat from $2.6 \%$ in 2005 to $3.1 \%$ in 2017, which indicated a $0.5 \%$ decline. However, female value declined from $68.8 \%$ in 2005 to $59.5 \%$ in 2017 (9.3\%) reduction. While the figure for female may be encouraging, due to $9.3 \%$ improvement between 2005 and 2017, it falls short of the expected improvement when compared to male counterparts (59.5\% vs $3.1 \%$ ) for female and male respectively. The finding is equally indicative that, more Malaysia women are adopting paid work with concomitant flexibility instead of caregiving responsibilities. What is not clear from the chart is whether increase in education attainment, crushing economic condition or work and life balance are influencing the demand for more paid work for female.

World economic forum (2018) report on global gender gap outlined for indicators of gender gap: political empowerment, health and survival, educational attainment and economic participation. From the report, political empowerment accounted for the increasing gender disparity, followed by economic opportunity, education attainment, health and survival. From the 2018 report, Malaysia was placed 101 out of the 149 countries surveyed, which is below the ranking of her neighbours such as Singapore $\left(67^{\text {th }}\right)$, Philippines $\left(8^{\text {th }}\right)$, Thailand $\left(73^{\text {th }}\right)$, Indonesia $\left(85^{\text {th }}\right)$, Sri Lanka 
$\left(100^{\text {th }}\right)$, Myanmar $\left(88^{\text {th }}\right)$, Viet Nam $\left(77^{\text {th }}\right)$. The information showed that Malaysia has falling behind in the context of gender equality compared to her neighbours.

While, educational opportunities have improved the fortune of females in labour participation, the aftermath of Covid 19 pandemic has worsened the situation. According to Mahajan, White, Madgavkar \& Krishnan (2020) on Harvard business review, three critical outcomes of Covid 19 pandemic have affected women disproportionately. First, women are 1.8 times more susceptible to Covid-19 related job losses compared to men. Second, women accounted for $39 \%$ of global employment and $54 \%$ of total employment losses. Third, caregiving and related unpaid work which increased due to Covid-19 disproportionately affected women.

\section{Conclusion}

The current structural economic imbalances means that, despite increasing gender supportive behaviours in some countries and regions, gender disparity still exists across board. Even though, the current review is not intended to cover all aspect of gender discriminations in Malaysia; it clearly brings to fore, the urgent need to address structural and institutional impediments which have become the cog on the wheel of enthroning gender egalitarianism. The following conclusions were drawn based on the findings from the review. First, majority of Malaysia women who are eligible to work are still not allowed to participate and or work in many segments of the economy due to religious and cultural sentiments. Second, these occupational or career restrictions may be attributed to widening gap of $25.4 \%$ of female labour force participation in 2017.

Third, while education attainment has improved female labour participation in Malaysia. The effect may be described as negligible when compared male. For example, even though the proportion of Malaysian adult women who are involved in home and care giving declined from $68.8 \%$ in 2005 to $59.5 \%$ in 2017 , representing (9.3\%) increase, it was insignificant compared to male. Finally, it was discovered that high number of women are involved in low paying jobs and in sectors that are more susceptible to economic headwinds such as tourism. This explains why more women were disproportionally affected in the midst of Covid-19 pandemic.

\section{Recommendations}

The following recommendations are necessary in the context of the findings. First, public advocacy should be improved within the religious and cultural settings in other to allow greater number of females to participate in some of the restricted sectors. This is necessary to ensure that increased in educational attainment by females are fully maximized in the larger economy. Second, the widening gap in female labour participation in Malaysia, compared to males would be improved through a streamlined labour laws and regulations to address some of the structural impediments against females. Although, educational opportunities have improved the prospects of female in labour participation, majority off women are attracted to liberal arts and humanities instead of physical sciences which are dominated by male; hence there is need to motivate more women to pursue those careers in physical and natural sciences in other to improve their career choices, economic and social standing. 
INTERNATIONAL JOURNAL OF ACADEMIC RESEARCH IN PROGRESSIVE EDUCATION AND

DEVELOPMENT

Vol. 10, No. 2, 2021, E-ISSN: 2226-6348 @ 2021 HRMARS

\section{References}

Alon, T., Doepke, M., Olmstead-Rumsey, J., \& Tertil, M. (2020). "The Impact of COVID-19 on Gender Equality.

Alwin, D. F., \& McCammon, R. J. (2003). Generations, cohorts, and social change. In J. T. Mortimer, \& M. J. Shanahan, Handbook of the life course (pp. 23-49). New York: Kluwer Academic/Plenum Publishers.

Banerjee, M. (2019). Gender Equality and Labour Force Participation: Mind the Gap. Antyajaa: Indian Journal of Women and Social Change, 4(1), 113-123.

Bolzendahl, C. I., \& Myers, D. J. (2004). Feminist attitudes and support for gender equality: Opinion change inwomen andmen, 1974-1998. Social Forces, 83(2), 759-789.

Chee, K. C., \& Gong, R. (14 March, 2019). Gender Role Values: What Do Women Want? Retrieved 2 April, 2021, from http://www.krinstitute.org/Discussion_Papers-@Gender_Role_Values-;_What_Do_Women_Want\%5E.aspx

Davis, S. N., \& Greenstein, T. N. (2009). Components predictors, and consequences. Annual Review of Sociology. Annual Review of Sociology, 35(1), 87-105.

Djankov, S., Trumbic, T., \& Zhang , E. Y. (2020). The gender gap and COVID-19: Evidence from eight advanced economies. Retrieved 31 March, 2021, from https://voxeu.org/article/covid-19-and-gender-gap-advanced-economies

Sani, D. G. M., \& Quaranta, M. (2017). The Best Is Yet to Come? Attitudes Toward Gender Roles Among Adolescents in 36 Countries. Sex Roles, 77(1-2), 30-45.

Greenhaus, J. H., Peng, A. C., \& Allen, T. D. (2012). Relations of Work Identity, Family Identity Situational Demands, and Sex with Employee Work Hours. Journal of Vocational Behavior, 80, 27-37. doi:10.1016/j.jvb.2011.05.003

Hyde, J. S. (2014). Gender Similarities and Differences. Annual Review of Psychology, 65, 373398. doi:doi:10.1146/annurev-psych-010213-115057.

Jolly, S., Griffith, K. A., DeCastro, A., Stewart, P., \& Jagsi, R. (2014). Gender Differences in Time Spent on Parenting and Domestic Responsibilities by High-Achieving Young PhysicianResearchers. Annals of Internal Medicine, 160, 344-353. doi:10.7326/M13-0974

Kelly, S., Watt, A., Hardie, N., \& Lawson, J. (2021). Boosting women's labour-force participation to lift long-term growth. Retrieved 31 March, 2021, from https://voxeu.org/article/boosting-women-s-labour-force-participation-lift-long-termgrowth

Kesler, C. (2018). Gender Norms, Work-Family Policies, and Labor Force Participation among Immigrant and Native-born Women in Western Europe. Socius: Sociological Research for a Dynamic World, 4, 1-16.

Lagarde, C. (2014). Daring the Difference: The 3 L's of Women's Empowerment," remarks by IMF Managing Director made at the National Democratic Institute. Washington, DC: National Democratic Institute.

Lagarde, C., \& Ostry, J. D. (2018). "The macroeconomic benefits of gender diversity. Retrieved 29 March, 2021, from https://voxeu.org/article/macroeconomic-benefits-gender-diversity

Landivar, L., Ruppanner, L., W Scarborough, W., \& Collins, C. (2020). Early signs indicate that COVID-19 is exacerbating gender inequality in the labor force. SOCIUS, 6, 1-3. Retrieved 
INTERNATIONAL JOURNAL OF ACADEMIC RESEARCH IN PROGRESSIVE EDUCATION AND

DEVELOPMENT

Vol. 10, No. 2, 2021, E-ISSN: 2226-6348 @ 2021 HRMARS

31 March, 2021, from

https://journals.sagepub.com/doi/pdf/10.1177/2378023120947997

Mahajan, D., White, O., Madgavkar, A., \& Krishnan, M. (2020). Don't Let the Pandemic Set Back Gender Equality. Harvard Business Review.

Moodley, T. (2018). Progression of South African Women in The Workplace: A Study of The Right to Development and Relevant Legal Framework That Underpins the Eradication of Gender Disparity in The Workplace. Kwazulu-Natal: University of Kwazulu-Natal. Retrieved 3 April, 2021, from https://ukzndspace.ukzn.ac.za/bitstream/handle/10413/18437/Moodley_Therusha_2018.pdf?seque nce $=1 \&$ isAllowed $=y$

Mottaghi, L. (2019). Invest in women to boost growth in MENA. Retrieved 2 April, 2021, from https://blogs.worldbank.org/arabvoices/invest-women-boost-growth-mena

OECD. (2016). Closing Gender Gaps in the Labour Market of Emerging Economies: The Unfinished Jobs. Paris: OECD.

OECD. (2017). The Pursuit of Gender Equality: An Uphill Battle. Paris: OECD Publishing.

Okpara, J. O., Squillace, M., \& Erondu, E. A. (2005). “Gender Differences and Job Satisfaction: A Study of University Teachers in the United States. Women in Management Review, 20, 177- 190. doi:10.1108/09649420510591852.

Olivetti, C., \& Petrongolo, B. (2017). The Economic Consequences of Family Policies: Lessons from a Century of Legislation in High-income Countries. The Journal of Economic Perspectives, 31(1), 205-230.

Powel, G. N., \& Butterfield, A. (2013). Sex, Gender, and Aspirations to Top Management Who's Opting Out? Who's Opting In? Journal of Vocational Behavior, 82, 30-36. doi:10.1016/j.jvb.2012.11.003

Röder, A., \& Mühlau, P. (2014). Are They Acculturating? Europe's Immigrants and Gender Egalitarianism. Social Forces, 92(3), 899-928.

Stamarski, C. S., \& Son Hing, L. S. (2015). Gender inequalities in the workplace the effects of organizational structures, processes, practices, and decision makers' sexism. Frontiers in Psychology, 5, 1-20. Retrieved 1 April, 2021, from file:///C:/Users/MY\%20HP/Downloads/fpsyg-06-01400.pdf

Thijs, P., Grotenhuis, M. T., Scheepers, P., \& Van den Brink, M. (2019). The Rise in Support for Gender Egalitarianism in the Netherlands,1979-2006: The Roles of Educational Expansion, Secularization and Female Labor Force Participation. Sex Roles, 81, 594-609. Retrieved 1 April, 2021, from https://link.springer.com/content/pdf/10.1007/s11199019-1015-z.pdf

World Bank. (2019). Breaking Barriers Toward Better Economic Opportunitiesfor Women in Malaysia. World Bank. Retrieved 30 April, 2021, from https://openknowledge.worldbank.org/handle/10986/32476

World Economic Forum. (2015). The global gender gap report 2015. Geneva: World Economic Forum. Retrieved 1 April, 2021, from http://www3.weforum.org/docs/GGGR2015/cover.pdf 
INTERNATIONAL JOURNAL OF ACADEMIC RESEARCH IN PROGRESSIVE EDUCATION AND

DEVELOPMENT

Vol. 10, No. 2, 2021, E-ISSN: 2226-6348 @ 2021 HRMARS

World Economic Forum. (2018). The Global Gender Gap Report. Geneva: World Economic Forum. Retrieved 3 April, 2021, from

http://www3.weforum.org/docs/WEF_GGGR_2018.pdf 